\title{
How conservatism makes peace with Trump
}

\author{
Philip N. Cohen \\ University of Maryland, College Park \\ pnc@umd.edu
}

Posted July 11, 2018; revised July 21, 2018

This essay is a review of Suicide of the West: How the Rebirth of Tribalism, Populism, Nationalism, and Identity Politics is Destroying American Democracy, by Jonah Goldberg (Crown Forum, 2018), with a few data explorations along the way. I read the book to see what I could learn about contemporary conservative thinking, especially anti-Trump conservatism. Opposing Trump and the movement he leads is suddenly the most pressing progressive issue of our time, and it's important not to be too narrow in mobilizing that opposition. ${ }^{1}$ Unfortunately, I found the book to be an extended screed against leftism with but a few pages of anti-Trump material grafted in here and there, which ultimately amounts to blaming leftism and immigration for Trump. And that might sum up the state of the anemic conservative movement. Goldberg's own weak-kneed position on Trump is not resolved until page 316, when he finally concludes, “As much as I hold Trump in contempt, I am still compelled to admit that, if my vote would have decided the election, I probably would have voted for him” (316). In the end, Goldberg has charted a path toward a détente between his movement and Trump’s.

The five White men who blurbed Suicide give an indication of the intellectual leadership status Goldberg occupies. They include Goldberg's employer at the American Enterprise Institute, Arthur Brooks ("wit and erudition”), John Podhoretz ("extraordinary erudition”), and his fellow fellow (and tax-deduction beneficiary) Charles Murray ("intellectual ... compelling thesis ... massive evidence ... Jonah Goldberg is that good”). This is supposed to be a serious work of conservatism, but it reads more as conservatism negotiating the terms of its surrender to authoritarianism, under a gloss of pseudo-intellectualism.

\footnotetext{
${ }^{1}$ Cohen, Philip N. 2017. “How I Choose Sides like It’s 1934.” Family Inequality. January 16, 2017.
} https://familyinequality.wordpress.com/2017/01/16/how-i-choose-sides-like-its-1934/. 
After an introduction on tribalism, I offer probes into specific aspects of the book: Blaming Howard Zinn for the state of America, attributing all good things in the world to capitalism, the question of erudition, and turning himself into knots to make his theory fit within mainstream family conservatism. Two of these discussions involve data explorations that spill into appendices at the end, to cut down on technical clutter. After a number of tangents that are not essential to the main point, but serve to undermine confidence in Goldberg's scholarship, I conclude on the issue of conservatism and Trumpism.

\section{Lazy tribalists are coming for your wealth}

In a book-promotion interview on NPR, Goldberg criticized what he called an "asinine cottage industry on the right that says that we need, essentially, an identity politics for white people."2 That seemed promising. But the interview, coming on the heels of an incident in which two Black men were arrested for doing nothing at a Starbucks, revealed Goldberg as a highbrow purveyor of All Lives Matter I Don't See Race-ism. Here's an excerpt:

GOLDBERG: You know, I think discrimination is repugnant. My whole point is you're supposed to take people as you find them. I am not saying we don't have racial problems in this country. I what I'm saying is, is that, if it's bad to reduce two black guys in a Starbucks to a - just simply a - they're members of a category, and therefore, I distrust them...

INSKEEP: Call the police.

GOLDBERG: Yeah, that's bad. It's also bad to say that I'm responsible for the stupid mistake or the stupid, you know, misjudgment of a Starbucks manager in Philadelphia.

INSKEEP: You don't like being blamed for that as a white person. That's what you're saying.

GOLDBERG: But I also don’t like thinking of myself as a white person.

On Twitter I referred to that last line as "the most white-person comment ever."3 His response was funny and led to this exchange ${ }^{4}$ :

Goldberg: So is "I think of myself as a white person" less of a white-person thing to say? Walk me through this.

Cohen: Ironic! Fact is no one doesn't like to think of their race as much as white people. Ask the Census Bureau who leaves the "race" question blank the most.

Goldberg: Okay. And do you think the country will be better off if that changes and we encourage those millions of Americans to think their racial "identity" is the most essential thing about them?

Cohen: No, I can’t say I do.

So, call it a paradox of dominant-group identity: celebrating it is bad, and denying it is bad, too. This leaves people like me in the extremely holier-than-thou-seeming position of apparently telling Whites

${ }^{2}$ NPR Morning Edition. 2018. “Goldberg’s ‘Suicide of the West’ Tackles Ills Of Identity Politics.” NPR.Org. April 23, 2018. https://www.npr.org/2018/04/23/604854281/goldbergs-suicide-of-the-west-tackles-ills-of-identitypolitics.

${ }^{3}$ Cohen, Philip N. 2018. “'I Don’t like Thinking of Myself as a White Person,' Says @JonahNRO, in the Most White-Person Comment Ever.” Tweet. @familyunequal. April 23. https://twitter.com/familyunequal/status/988394471187468291.

${ }^{4}$ Goldberg, Jonah. 2018. Tweet. @JonahNRO. April 23. https://twitter.com/JonahNRO/status/988395152631848960. 
(like me) that what they should do is acknowledge their White identity but as a bad thing. Fortunately, it's not my job to tell individuals how to manage their identities. Incidentally, there really is data on this, and it shows that Whites are the most likely to leave the race question blank on Census surveys; this is detailed in Appendix A.

Although Goldberg doesn't identify them, the people not answering the race question are living on the higher plane of civilization upon which he sees himself perching, the plane above tribalism. To tie this to his main argument, here's the short version: "Democratic capitalism” isn't "natural” vis-à-vis human nature, it is "the Miracle," and if the U.S. doesn't actively defend it (in particular by showing "gratitude" for the gifts it bestows) then society will revert back to a more natural state of "tribalism." In theory, the path back down to tribalism can lead to the left or the right. "Conceptually," he writes, "we have reached the end of history. We are at the summit, and at this altitude left and right lose most of their meaning. Because when you are at the top of a mountain, any direction you turn ... the result is the same: You must go down, back whence you came” (350). But of course he sees the left as leading the way down - driving not toward a higher level of civilization (bending the arc toward justice), but back toward a primitive past - and the misguided right merely falling victim to the left's beguiling charms. ("The grave danger, already materializing," he writes, "is that Whites and Christians respond to [the left's] bigotry and create their own tribal identity politics” [233].)

As an aside, although Goldberg says he would have voted for Trump, I should add that I do appreciate his criticism of the Trump in these early days of Trumpism, and the use of his platform to support opposition to Trump's presidency is positive. However, the idea that, in 2018, "left and right lose most of their meaning," posing equivalent threats to our status at the pinnacle of social evolution, is ignorant analysis and reactionary politics. Trump poses an existential threat to democracy; Black Lives Matter does not.

Anyway, Goldberg's theory glides along with a breezy incoherence. For example, he writes both that, in capitalist democracy, "you're standing at the end of history" (14), and also that, "There is no "right side of history.' Nothing is foreordained” (4). And there are some displays of historical erudition that will surely leave less civilized historians, and biologists, scratching their heads:

The free-market system is not merely the best anti-poverty program ever conceived; it is quite literally the only anti-poverty system ever invented. Poverty is the natural human condition, and it remained the steady state of human affairs for nearly all of human history. Socialism as a label is a relatively recent invention. But socialism as an idea is beyond ancient. Socialism is the economics of the tribe. We evolved as a cooperative, resource-sharing species. This is one reason why the idea of socialism keeps coming back. It's in our brains, alongside myriad other factorypreset ideas and desires: that capitalism is unnatural; individual liberty and free speech are unnatural; liberal democratic capitalism is at war with human nature in every generation (378).

Besides it's other deficits, that numbingly superficial characterization of socialism is emblematic of Goldberg's approach to all opponents of his enlightened position - he apparently does not read, and certainly doesn't substantively engage, either the research on socialism, identity politics, and so on, or the writing of those who do. These subjects have histories, and those histories do not reduce to "tribalism."

The theory dictates that any politics of the group, rather than the individual, is tribalist, and therefore only abstracted individualism, in the body of Goldberg himself, represents advanced civilization. "Identity politics' may be a modern term," he writes, "but it is an ancient idea. Embracing it is not a step forward but a retreat to the past" (61). (Historians will appreciate that he has ranked socialism "beyond ancient," which is apparently even older than identity politics, which is merely "ancient.”) The mysteries of erudition know no bounds. 
This is how Goldberg gives the appearance of coherence while linking "identity politics" to "every anticapitalism political ideology" which are all "a variant of the idea that society should operate like a family, a tribe, a small community where everyone knows each other. Identity politics in all its forms is just a subset of this worldview. It says 'My tribe deserves more than your tribe" (64). This is only true at the meaninglessly abstract level that anti-capitalism tends to be collectivist and identity politics works on group identity. It's literally saying everything that's not free-market capitalism is the same: socialism, communism, anarchism, feminism, left-wing nationalism, right-wing nationalism, as well as families, organized crime, and small communities are all a "subset of the worldview" that groups matter. It is almost as if he thinks any form of organized cooperation is reflecting of "the premodern or tribal mind," which "despises division.” He writes, "Whether it takes the form of religious orthodoxy, communist dogma, the divine right of kings, or some variant of 'social justice' theory, the same underlying impulse rules. We must all be in it together" (86-87).

This is not useful for understanding society, but it is useful for blaming Trumpism and White nationalism on leftists, which is Goldberg's proximate purpose. It's not a coincidence that Goldberg labels all politics of subordinate groups as exhibiting pre-civilized status. When Chris Hayes, in his podcast interview with Amy Chua, commented on people who criticize Black Lives Matter for being tribalist, he might as well have been speaking of Goldberg: "Someone comes in and says these are tribal politics there, they have tacitly elevated themselves to someplace where they're in the view from nowhere, floating above it, and all of you messy little humans are just fighting about tribal stuff." 5

As it happens, Goldberg's only mention of Black Lives Matter (in passing, with no references) is this withering critique: "Whatever you make of the underlying merits of the issues related to the Black Lives Matter movement, symbolically it is very much an argument about the relative status of groups” (325). Well, yes. As is the case with almost all political movements. Since group politics has always been essential for resistance to oppression, this devolves into the argument that any substantive opposition to the status quo is a problem. And that's a strikingly unoriginal, and uninteresting, perspective. When everyone else is a tribalist, the last man standing on that higher plane - at the American Enterprise Institute - is the only one with a truly universal perspective. Here is how Bourdieu paraphrased Marx: "the ideologue is the one who posits as universal, as disinterested, that which is in accordance with their particular interest." 6

Rather than see the "social justice warriors," feminists, socialists, or anyone else working to oppose inequality and oppression as contributing something of value to social development, he sees their progress-crushing primitivism as a form of laziness, reflecting lack of effort. "Without effort, civilization dies, because that is what civilization is: effort” (65). So don't let anyone tell you these activists are making an effort to improve society; they are really just trying to let society collapse back into a state of nature. Similarly, don't believe poor people work harder than rich people: "Poverty is natural; wealth takes effort” (66).

\section{The Howard Zinn meme}

In the opening pages Goldberg writes:

\footnotetext{
${ }^{5}$ Hayes, Chris. 2018. “Why Is This Happening? With Chris Hayes.” ART19. June 12, 2018. https://art19.com/shows/why-is-this-happening-with-chris-hayes. Chua's new book is: Chua, Amy. 2018. Political Tribes: Group Instinct and the Fate of Nations. New York: Penguin Press. ${ }^{6}$ Bourdieu, Pierre. 1998. Practical Reason: On the Theory of Action. Stanford University Press. p. 89.
} 
"We are shot through with ingratitude for the Miracle. Our schools and universities, to the extent they teach the Western tradition at all, do so from a perspective of resentful hostility toward our accomplishments. ... Consider Howard Zinn's People's History of the United States. Published in 1980, it has sold millions of copies and remains one of the most widely used texts in America ... By turning the Founders into nothing more than greedy white racists, by decrying Columbus as nothing more than a genocidal murderer, by arguing that slavery is a uniquely Western and American sin, by claiming that 'Western civilization' and 'American exceptionalism are nothing more than euphemisms for 'racism' and 'imperialism,' the ressentiment-drenched intellectuals at the commanding heights of our culture seek to make the story of the Miracle into a Curse, leaving them as the only legitimate storytellers of our civilization” (16-17).

Imagine living in a world where American schools may or may not "teach the Western tradition at all" and Howard Zinn is standing at the "commanding heights of our culture." (A Google search for the phrase "Western Civilization term paper," returns 50,000 web pages; one for "Howard Zinn term paper" returns 510.) Zinn occupies a central position in this fictional narrative of narratives, and the claim that his book dominates our schools' teaching of history is decisive - it's the only piece of evidence Goldberg offers for the content of American history education, and the only evidence for this dominance is that the book has a very high Amazon sales ranking. He adds, "It [Zinn] remains one of, if not the most, widely used textbooks in American high schools and colleges" (382). This claim is not true, and it was debunked a long time ago.

This might seem a trivial anecdote (unless of course Zinn actually was the foundation of American history education). Goldberg heard a meme he liked, one that dates back at least to 2005; he did a sloppy Internet search to confirm what he already believed, and put it in the book. But it also shows the hollowness of his scholarship, his approach to evidence, and the lack of substantive engagement with what he claims to be critiquing. And his refusal to admit he is wrong (which I show below) indicates a lack of integrity.

One could make a case that American education doesn't teach an unadulterated appreciation for the benefits of capitalism and is too critical of the America in American history. In my case, for example, when I taught a course on social inequality undergraduates, I used to assign the Communist Manifesto, but no capitalist manifesto for balance. I told them Marx's was an important critique to understand, and that it was important to read a fundamental critique of the status quo, whatever that status quo is. I did not balance that with a pro-capitalist treatise because we live in a pro-capitalist treatise. Still, I did also teach that markets work well for some things, like setting prices and allocating resources, within limits. So, one could criticize my approach, which was probably a popular one. Instead of engaging the ongoing, widespread debate about the content of education at the high school and college levels, however, Goldberg took his single-fact meme on the road, repeating it in a series of book-promoting media interviews with credulous, like-minded friends.

Here are some examples (leaving in his misstatements of the book’s title):

- In his interview with Bill Kristol: "If you look at, like, say, Howard Zinn’s History of the American People, what he does is he says - he's explicit about it. Most widely read history textbook in America, right? Still. And he says, 'My history of America is the history from the view of the Native Americans, from the slaves, history of the - from the Trail of Tears, from the 
oppressed coal miners,' right? It's just one victim group after another, and what he's doing is saying that this is the only usable history that we can have."

- In his interview with Robert Wright: "If I had to sort of pick a villain in all of this, which I don't want to do, I would say that the sort of Howard Zinn version of America - you know, Howard Zinn's People's History of America, it’s still the number one, I believe the number one, history text in America, in high school and colleges."

- In his interview with John Podhoretz: "The way we teach Western civilization today, the way we teach American history today, it is just the concatenation of all the negative stuff, right? And Howard Zinn is open about this. He says - [Podhoretz interjects: Howard Zinn is the author of The People's History of the United States, which I think is the most assigned now, or one of the most assigned.... - still the most widely used history text in America. ${ }^{9}$

What is the purpose of always describing the book as "still" the most widely used text? Maybe it implies Goldberg has researched this question, is monitoring the situation. Maybe it brings listeners in with a sense that we have a common knowledge that it used to be the most widely used, but his surprising finding is that it still is. I'm not sure. Maybe what really galls Goldberg is Zinn's status among the cool kids of the culture. He let this show in his Twitter critique of the film Good Will Hunting (in which the radical genius character praises Zinn), writing: "I mean the whole idea that Howard Zinn is the ultimate authority on American history basically defines pseudo intellectual d-baggery." ${ }^{10}$ I find that comment ironic, given it is Goldberg falsely elevating the status of Zinn, and using the tools of pseudointellectualism - "if you look at, say, Howard Zinn..." as if in his book he surveyed the landscape of history curricula and identified this key work as particularly emblematic - to promote his narrative to that effect. $^{11}$

The story of Zinn dominating American history education is not only completely untrue, it's also not original to Goldberg, who is merely one in a long chain of conservative talking heads to repeat it without evidence. The earliest incidence of the meme I found was the August 14, 2005 edition of The Ukranian Weekly, where the Ukranian nationalist Myron B. Kuropas called it, without evidence, "the most popular textbook on American campuses today."12 It got a bounce in 2010, when Zinn died. Roger Kimball in National Review referred to the book’s high Amazon sales rank (no doubt boosted that week by death-

7 “Jonah Goldberg IV Transcript.” 2018. Conversations with Bill Kristol (taped April 13, 2018). http://conversationswithbillkristol.org/transcript/jonah-goldberg-iv-transcript/.

${ }^{8}$ Bloggingheads.tv. 2018. Suicide of the West | Robert Wright and Jonah Goldberg [The Wright Show]. https://www.youtube.com/watch?v=UZxVAxGK6Zw (At 26:00).

${ }^{9}$ C-SPAN.org. 2018. “After Words, Jonah Goldberg.” April 26, 2018. https://www.c-span.org/video/?4444271/after-words-jonah-goldberg.

${ }^{10}$ Goldberg, Jonah. 2017. Tweet. @JonahNRO. June 25, 2017. https://twitter.com/JonahNRO/status/879137028545359875.

${ }^{11}$ In fact, Will's knowledge of American history, as depicted in the classic, “How do you like them apples?” bar scene, is supposed to be based on reading many books of original scholarship; he uses the absence of Zinn on the shelf to critique the psychologist's presumed non-critical political views, not as the "ultimate authority" on history. ("You wanna read a real history book, read Howard Zinn's People's History of the United States. That book'll fuckin' knock you on your ass.") That is probably a reasonable representation of how Zinn is used, not as a "textbook" but as an iconic voice of the radical left perspective.

${ }^{12}$ Kuropas, Myron B. 2005. "When it comes to American history, revisionists rule!” The Ukranian Weekly August 14, p. 7. http://www.ukrweekly.com/archive/2005/The_Ukrainian_Weekly_2005-33.pdf. Accessed June 16, 2018. 
related sales). ${ }^{13}$ And he wrote, "A People's History is the textbook of choice in high schools and colleges across the country. No other account of our past comes even close in influence or ubiquity.” In addition to his Amazon search, Goldberg cites Kimball, whose only evidence was an Amazon ranking (Goldberg also includes the same 134-word excerpt from Zinn's introduction that Kimball used in his article.)

Also in 2010, then-Indiana Gov. Mitch Daniels was furious at the positive coverage Zinn received upon his death. And he ordered an investigation into whether Zinn's book was "in use anywhere in Indiana," according to emails later uncovered by the Associated Press. The result of his investigation, was nothing. Oops. He told the A.P. in 2013, "It was encouraging to find that no Hoosier school district had inflicted his book on its students."14 Nevertheless, the meme was subsequently featured prominently in a 2015 speech to the National Rifle Association by presidential candidate Rick Santorum, who said, "Do you know the most popular textbook that's taught in our high schools in America is written by a man named Howard Zinn, who is an anti-American Marxist, and that is the most common textbook?” It was this speech that finally prompted a debunking by Politifact, which applied the verdict Mostly False to the claim. $^{15}$

When there is no evidence offered for a meme, you shouldn't have to prove it's not true - it's not really up to the debunkers to solve the problem of the meme. ${ }^{16}$ Here, as so often happens, Politifact and I have spent much more time debunking this than Goldberg and his fellow mythmakers spent bunking it in the first place. Politifact laid out the case well. First, People's History is not a textbook, it's a trade book. It simply doesn't play the role of history survey textbooks, as a cursory reading would make clear. When people cite its high position on Amazon's list of best-selling “textbooks” as evidence, they shouldn't. I don't know how Amazon makes that list, but it's not a list of textbooks (at this writing current leaders include not only Zinn, but many test-preparation manuals; The Elements of Style; Guns, Germs, and Steel; and the 2019 Rand McNally Road Atlas). Perhaps more importantly, that list doesn't differentiate between course sales and other sales. So if a book is popular off campus, but also used in some classrooms, it might appear high on the "textbook" list despite being rarely assigned in school.

The book is certainly popular and influential; it has iconic status as a general critique of mainstream history on the left. But it's not commonly assigned in college or high school classrooms, and certainly not as a primary survey text. Politifact cites a survey of 258 college undergraduate history courses, which found Zinn on three syllabuses. ${ }^{17}$ No state lists it on the adoption list of history textbooks. I consulted the Open Syllabus Project database, and found Zinn on 48 syllabuses, compared with 586 syllabuses that

${ }^{13}$ Kimball, Roger. 2010. “Professor of Contempt.” National Review. February 3, 2010. https://www.nationalreview.com/2010/02/professor-contempt-roger-kimball/.

${ }^{14}$ Stripling, Jack. 2013. “In E-Mails, Former Indiana Governor Wanted Scholars Silenced.” The Chronicle of Higher Education, July 16, 2013. https://www.chronicle.com/article/In-E-Mails-Former-Indiana/140401.

15 Jacobson, Louis. 2015. “Is Book by Howard Zinn the ‘most Popular’ High-School History Textbook?” Politifact. April 15. http://www.politifact.com/truth-o-meter/statements/2015/apr/15/rick-santorum/book-howard-zinnmost-popular-high-school-history-/.

${ }^{16}$ I make this case in a review and debunking of the "women own 1 percent of all wealth in the world" meme in Cohen, Philip N. 2018. Enduring Bonds: Inequality, Marriage, Parenting, and Everything Else That Makes Families Great and Terrible. Oakland, California: University of California Press.

${ }^{17}$ Cohen, Daniel J. 2015. "By the Book: Assessing the Place of Textbooks in U.S. Survey Courses - Roy Rosenzweig Center for History and New Media.” Accessed June 16, 2018. https://rrchnm.org/essay/by-thebook-assessing-the-place-of-textbooks-in-u-s-survey-courses/. 
include George Tindall Brown's America: A Narrative History, 263 with Richard Nelson Current's United States History, and hundreds of others that were more popular than Zinn. ${ }^{18}$

At the high school level, state public school curriculums are readily accessible, and they stand in glaring contradiction to Goldberg's narrative. While Goldberg bemoans the lack of "gratitude” toward our system, every social studies class in Texas and Florida is required to perform Celebrate Freedom Week, during which students are required to recite the introduction to the Declaration of Independence. Their U.S. history sequences center on the U.S. founding documents and require students to learn the importance of the free enterprise system. The regulations for these large states essentially describe Goldberg's desired curriculum. ${ }^{19}$ In more liberal California, high school students engage a curriculum in which, "Special attention is given to the ideological origins of the American Revolution and its grounding in the democratic political tradition and the natural rights philosophy of the Founding Fathers.” Although California's curriculum suggests such critical topics as "the emergence of a free, democratic system of government alongside an entrenched system of chattel slavery," and covers lots of the negative events Goldberg mentions, it concludes with the requirement that,

Students recognize that under the American democratic political system the United States has achieved a level of freedom, political stability, and economic prosperity that has made it a model for other nations: the leader of the world's democratic societies and a magnet for people all over the world who yearn for a life of freedom and opportunity. ${ }^{20}$

In New York, Goldberg would be glad to know - if he had troubled himself to do the relevant research that high school students are required to study Locke, Montesquieu, and Rousseau - and that Adam Smith is taught under economic development, while Marx is under "ideologies."21 America is not teaching Howard Zinn's curriculum.

Having performed a cursory review, and reading the Politifact piece, I confronted Goldberg on Twitter with the evidence, and he responded:

1. **Maybe** I shoulda said "one of" 2 . The politifact article you cite as your only evidence refers to high schools. 3. Politifact is unreliable. 4. At this moment PHUS is 11 on Amazon's list of bestselling textbooks. 5 . And it's the no. 1 history text. ${ }^{22}$

This is completely wrong. There is no evidence it is "one of" the most popular textbooks either. The Politifact article covered college and well as high school. Politifact linked to their sources, which are easily confirmed. And the Amazon list is not an appropriate source, as noted. When I replied that I had

${ }^{18}$ The database is searchable here: http://explorer.opensyllabusproject.org/ (accessed July 6, 2018). The right-wing American Textbook Council recently published a note on college and history textbooks, complaining about "dumbed down," "identity politics," and "diversity-based" books. They not the textbook sales figures are not publicly available, but still list seven "leading U.S. history textbooks," which do not include Zinn. See: http://historytextbooks.net/adopted.htm (accessed July 6, 2018).

${ }^{19}$ Texas Education Agency. n.d. “Texas Education Agency - 19 TAC Chapter 113.” Accessed July 8, 2018. http://ritter.tea.state.tx.us/rules/tac/chapter113/. State of Florida. 2018. K-20 Education Code. Chapter 1003: Public K-12 Education. Vol. XLVIII.

http://www.leg.state.fl.us/Statutes/index.cfm?App_mode=Display_Statute\&URL=1000-1099/1003/1003.html.

${ }^{20}$ California Department of Education. 2017. "History Social Science Framework."

https://www.cde.ca.gov/ci/hs/cf/documents/hssfwchapter16.pdf.

${ }^{21}$ New York State. 2017. "Grades 9-12 Social Studies Framework.”

http://www.p12.nysed.gov/ciai/socst/documents/9-12FrameworkRevFebruary2017.pdf.

${ }^{22}$ Goldberg, Jonah. 2018. Tweet. @JonahNRO. June 3, 2018.

https://twitter.com/JonahNRO/status/1003412890391543808. 
not found any evidence of Zinn being used in high schools - having looked at the curriculum standards for California, New York, Texas, and Florida, he replied,

You keep saying high school. I didn’t. If you want to argue about my phrasing, knock yourself out. But I say in my book "one of the mostly widely used texts in America.” That is inarguably true. I also say that the Zinn version of history **should be taught** btw. ${ }^{23}$

As noted, he also made the claim about high schools specifically, although he sometimes doesn't differentiate between high school and college. When I responded with an example of Florida's high school curriculum, which devotes more words to the Holocaust than to slavery, he replied, finally, "You're making an ass of yourself demolishing points I did not make. Are you just crazy mad or do you always operate in bad faith?”24

I can't speak to whether I was making an ass of myself, but I was not operating in bad faith, and provided links to my sources (as I have done here). Goldberg, who has more than 300 thousand followers on Twitter, might like to correct his public statements on that platform and in his book. In so doing, of course, he could do some actual research about the content of American history education, and make an argument about it. I for one would be glad to read that.

\section{Lazy ideologues are coming for your facts}

Goldberg backs up this image of the democratic capitalist mountain climb in an appendix with a long series of graphs, telling the well-known story of improving global living standards. In these figures Goldberg claims to show that "capitalism” is "the most liberating force in human history" simply because conditions improved over time; any positive trend in the world is attributable to capitalism. For example, he cites progress on literacy, this way: "As recently as 1820, only 12 percent of the world's population was literate. The wealth created by capitalism has changed all of this. By 2014 only 15 percent of the world's population remained illiterate" (373). He backs up that claim with a chart of change in average years of school attendance globally from 1950 to the 2000s. Similarly, after showing the global life expectancy trend, he declares, "Capitalism literally gives the average person 'new life' in the sense that old age was, for the average person, an unrealistic ambition” (369).

This is laughable as social science, as it fails to include any consideration of alternative causes for these changes that might coincide with the existence of capitalism. For example, those claims would be no more or less reasonable if you replaced “capitalism” with "science.” In fact, Goldberg may be surprised to learn many places in the world did not even have systems of capitalism during some the last few centuries. Most notable of these, because of both its size and its dramatic success on some aspects of development, is China. To illustrate this, I present global trends in literacy and life expectancy in Figure 1, with China and India shown. In both cases, China's development outpaces the rate of global improvement and, because of its size, contributes substantially to the global trend. India is a useful comparison because it can stand in for an alternative global trajectory in which China followed a much slower, capitalist path of development. Panel A shows literacy, with China's rapid rise after 1949 reflecting the spread of basic education. By 1980 (before its capitalist turn), China had reached 4.6 years of schooling, approaching the world average of 5.3, while India was at 2.7. Using the relative size of the population, it's easy to calculate that if China had remained just half a year ahead of India's education

\footnotetext{
${ }^{23}$ Goldberg, Jonah. 2018. Tweet. @JonahNRO. June 3, 2018. https://twitter.com/JonahNRO/status/1003414916722814976.

${ }^{24}$ Goldberg, Jonah. 2018. Tweet. @JonahNRO. June 3, 2018. https://twitter.com/JonahNRO/status/1003415297800527872.
} 
level, the global average would be a third of a year lower, 5.0 instead of 5.3. This alternative scenario is shown in the figure. I perform the same calculations for life expectancy in panel B. In the 1960s and 1970s China had a very rapid rise in life expectancy, from well below to 3.6 years above the global average. Again using the relative population sizes, we can see that if China had merely maintained its advantage over India, the global life expectancy would have been 59.9 instead of 62.2, or 2.3 years shorter. So, socialism literally gives the average person new life, too.
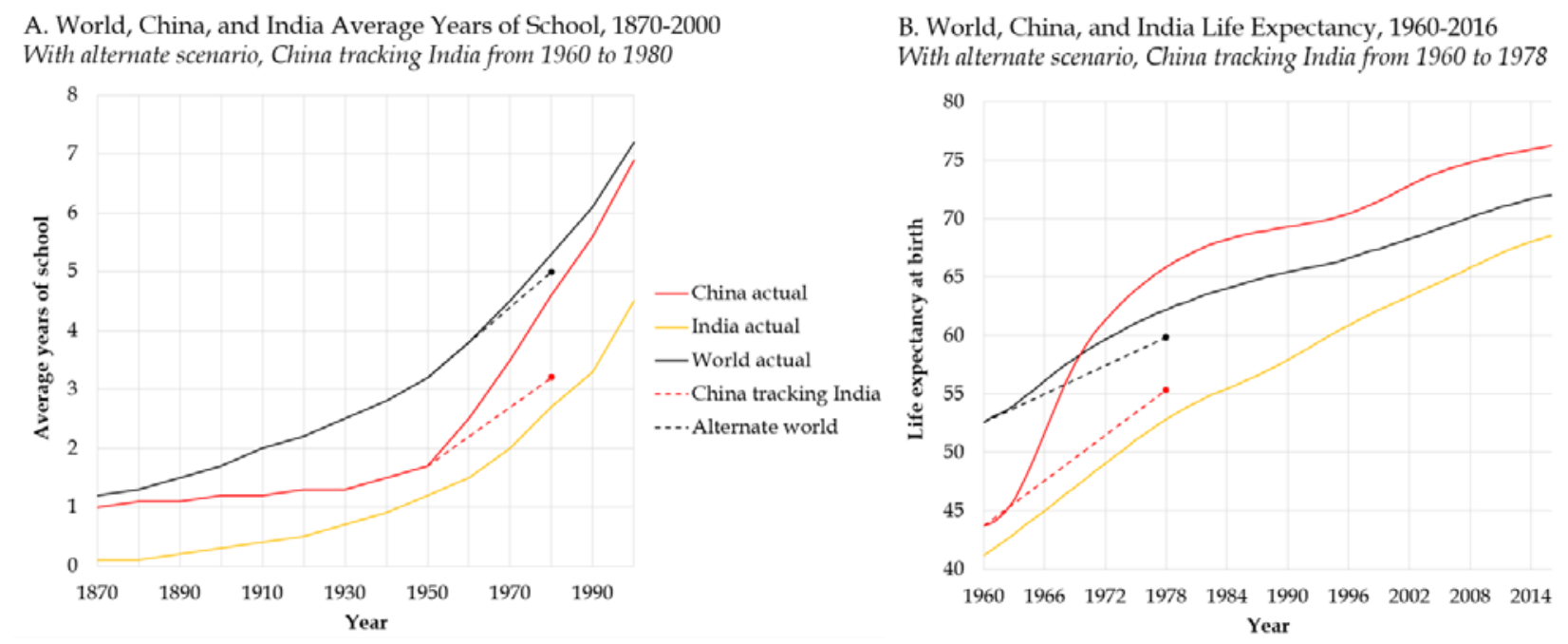

Figure 1. Impact of China's development (versus India's) on global trends in education and life expectancy. Data sources: Life expectancy and population estimates from World Bank data, years of school from OECD. ${ }^{25}$

The point of this exercise here is not to debate China's development (or anything else about China), but rather to use China's socialist development spurt to show the fallacy of Goldberg's claim that "democratic capitalism" is the one self-explanatory cause of human progress. ${ }^{26}$

As an aside, in most of Goldberg's graphs, the y-axis is truncated to make it look like the base is zero. For example, the percentage of world population having access to electricity is shown to have risen from 76 to 85 in recent decades - or, from the bottom to the top of the chart (364). And sometimes the base of the yaxis inexplicably is even labeled zero, as with life expectancy and infant mortality (Figure 2).

${ }^{25}$ Zenden, J. L. van, ed. 2014. How Was Life? Global Well-Being Since 1820. http://dx.doi.org/10.1787/9789264214262-en.

${ }^{26}$ Further beyond my expertise there are similarly baseless claims, such as, "Capitalism is ultimately good for the environment” (368), in describing how capitalist societies may be able to reduce some of the environmental harm cased by - capitalist societies. (Amazingly, he also reports global forest cover trends while excluding Brazil and Indonesia, for no stated reason [367].) 

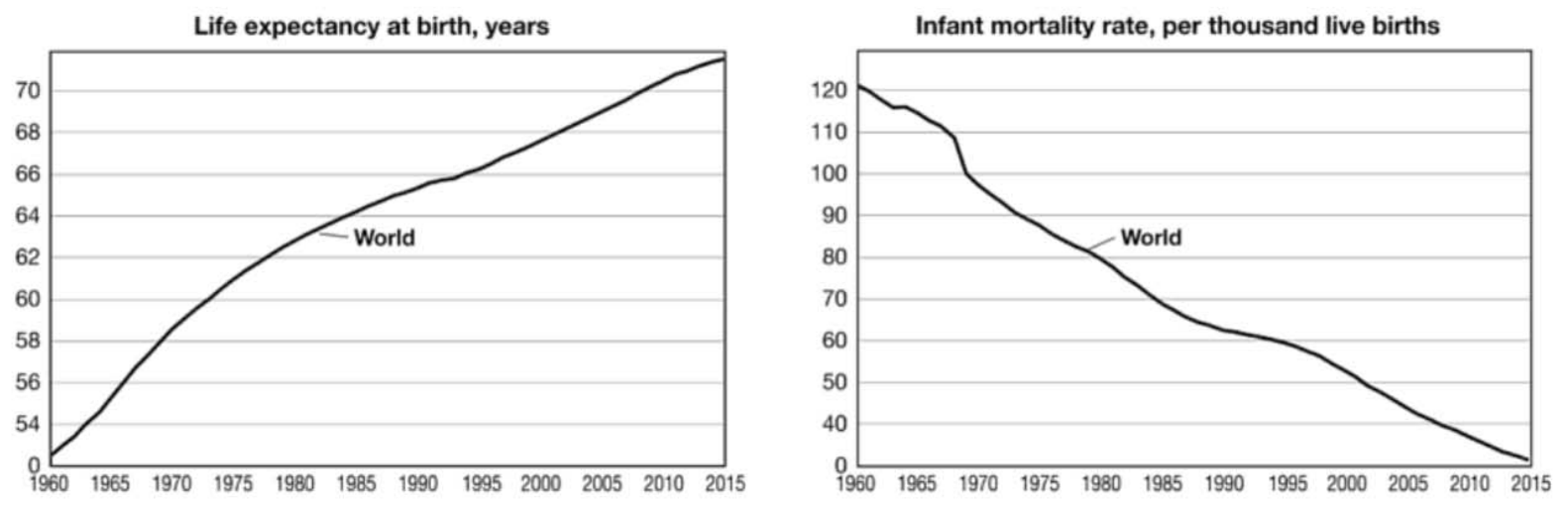

Figure 2. Two figures from Suicide of the West, with y-axis truncation and incorrect 0 labels (pp. 369, 370).

\section{Erudition}

Before moving to other substantive topics, a short tangent on erudition, that quality of Goldberg's work mentioned by several of his friends on the book jacket. Besides the fact that he writes a lot about the Enlightenment, one source for this perception may be Goldberg's frequent practice of defining words or phrases. Usually this is no more than banal filler reiterating the obvious meaning of the term. For example, he defines corruption ("the destruction of spoiling of anything" [48]), decadent ("decay or decaying” [49]), nepotism ("derived from the Italian nepotismo, drawn from the Latin nepos for 'grandchild,' and the root of 'nephew'” [55]), enforce ("Indeed, the very word 'enforce' literally means to use force" [76]). Sometimes these are wrong, as when he writes about governance through family alliances, "social scientists call this 'familism”" (56), which is not true (we use familism, as opposed to individualism, to refer to the high cultural value placed on family commitments ${ }^{27}$ ).

One of the more confounding linguistic tangents involves the connection between "our natural desire and tendencies to look to father figures" and the word patriotism. After listing a dozen or so leaders who used father imagery, from Stalin and Hitler and Mao to Mobutu and Putin, he concludes, “even when we remove the dogmas that elevate monarchy over democracy, the pattern [of father figure political leaders] holds more often than not.” Because of this pattern, it follows that "every ... secular authoritarian ruler of the last two centuries" cannot be said to have "imposed this role on their respective populations. The people asked for it” (85). I don’t recall seeing the existence of male dictators being chalked up to a natural desires for father figures, although I'm sure it's not an original argument. But Goldberg adds as a bit of erudition that patriotism "comes from the Latin patria, meaning fatherland, itself a derivative of pater, or 'father.'” This is an odd choice of supporting evidence, as some of the leaders mentioned, such as Mao, use words for patriotism (爱国主义) that do not have an origin or connotation of fatherhood. (Also, the

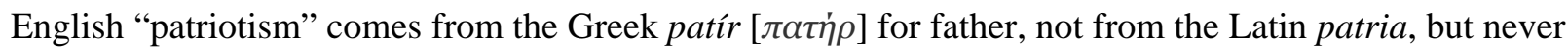
mind, the point is erudition. ${ }^{28}$ )

\footnotetext{
${ }^{27}$ Valdivieso-Mora, Esmeralda, Casie L. Peet, Mauricio Garnier-Villarreal, Monica Salazar-Villanea, and David K. Johnson. 2016. “A Systematic Review of the Relationship between Familism and Mental Health Outcomes in Latino Population.” Frontiers in Psychology 7. https://doi.org/10.3389/fpsyg.2016.01632.

${ }^{28}$ OED Online. n.d. "Patriot.” Oxford University Press. Accessed July 8, 2018. http://www.oed.com/view/Entry/138899\#eid31784971.
} 
In another case, it is the erudition of math that fails Goldberg. Complaining about the left's opposition to income inequality, he writes:

Today, there is a low-simmering Jacobin fever aimed at the so-called one percent. This bland description of economic elites is logically ludicrous, given that is a fact of math that there will always be a top one percent. ... Remove the top floor of a building and the next floor down becomes the top floor. The only way to ensure there is no top is to tear down the whole structure to the foundation. (54)

That is ridiculously untrue. It is only a fact of math that there will always be a top one percent in cases where there is a top tier that represents one percent of the population. Consider a simple example of a policy to reduce income inequality. Say you have 100 people, with incomes increasing by $\$ 1,000$ per person, so the poorest person gets $\$ 1,000$ and the richest gets $\$ 100,000$. There are 100 tiers, and the top one percent has $\$ 100,000$ in income. If the government takes $\$ 1,000$ in income from the richest person and gives it to the poorest person, now you have 98 tiers, with two people getting $\$ 2,000$ at the bottom, and two people getting $\$ 99,000$ at the top. There is no top 1 percent. In terms of Goldberg's building metaphor, there is always a top floor of a building, but if there are less than 100 floors there is no one living above 99 percent of everyone else. This is a pretty important social principle. Also, much as he would like to think of equality as "tearing down the whole structure," a one-story building also has no top floor, so there is no need to tear it all down to get equality. Instead of imposing his prior assumption through hapless metaphors or trying to use math, Goldberg would have been better served by just saying, "I believe high levels of inequality are good, and attempts to reduce inequality will destroy what is good about our society.”

The final kind of erudition occurs when Goldberg simply dresses up prosaic observations with sciencysounding gobbledygook, as in this case: "When someone cuts in line in front of us at the grocery store, there is a chemical reaction in our brains that fills us with anger" (41). If this kind of thing makes the reader feel smarter or more educated, I suppose there's no harm in it.

\section{Barbarism versus the family}

Many conservatives who promote the idea of limited government also support intrusive requirements and penalties on poor people or marginalized groups for their individual family choices, through the welfare system, marriage promotion programs, and restrictions on reproductive rights. So maintaining the conservative consensus that personal freedom with respect to family life is a privilege rather than a right requires a shared commitment to hypocrisy. Goldberg makes a contribution here to that effort, and it will no doubt ring true to those who share his prior assumptions. But other readers will be left scratching their heads.

In his chapter, “The Family’s Losing War Against Barbarism,” Goldberg has a particular problem in the contradiction between his concept of "natural" and the use of "traditional" with respect to families. Recall his theory is that democratic capitalism is not natural, it is a miraculous modern invention. Failing to defend that miracle will result in society sliding back down the mountain to tribalism. Where does "traditional" fit in to that scheme? With respect to capitalism and democracy, what is traditional is the problem - things like nepotism, and male dictators that gratify our inbred desire for domination by father figures. Of course, modernity by definition stands in opposition to what is traditional. ${ }^{29}$ So where does the traditional family fit it? That's different.

${ }^{29}$ Giddens, Anthony. 1990. The Consequences of Modernity. Stanford University Press. 
Discerning the underlying theory is difficult, through Goldberg's thicket of unfalsifiable claims and clichéd platitudes about families. "By any measure," he declares, "the most important mediating institution in any society is the family. Healthy, well-functioning families are the primary wellspring of societal success. Unhealthy, dysfunctional families are the primary cause of societal decline” (262). Such statements - which directly contradict his own claims about capitalism (see above) - are protestations of political affiliation with American conservatism, but have nothing to do with social analysis.

The term "mediating institution" is a clue, however, because that is close to his definition of civil society, which has something to do with families. He is certain that weak civil society undermines the social order. "The easiest illustration of this," he writes in the introduction, "is the way young men from dysfunctional homes and atomized communities have fallen in with street gangs for thousands of years in every corner of the globe" (12). He might have had a case if he had said "several decades" instead of "thousands of years," but as it is the claim hardly merits rebuttal. If civil society is the opposite of tribalism, what is civil society? Mediating institutions, he argues, are "the formal and informal organizations, customs, and rules that 'mediate' the space between the individual and the state, often called 'civil society'” (262). He thus includes families and churches in civil society, but for some reason not street gangs, the Klan, the Mafia, or progressive social movements. So it starts to seem as if civil society is defined by his evaluation of a collectivity's moral standing in his worldview. For example, churches "civilize" people (13), but Marxism is bad because he spoke of "the workers of the world, bound together in tribal solidarity” (14). In his mind, religious order binds people together in civil society while, say, the Black Lives Matter movement binds people into an uncivilized tribe.

Following this thread, "the healthy family is also the keystone of civil society," because it is between the individual and the state. But that starts to crumble in the next sentence, "Many of the most important mediating institutions relate not simply to individuals but to the families behind them" (262). So are families mediating institutions, or are they like individuals, needing to mediate their relationship to the state? My understanding of the civil society literature, which is admittedly limited, is that families are generally not considered to be part of civil society, because they are in the private sphere, representing not collective interests but individual ties. The World Bank definition of civil society is the sphere of formal nongovernmental organizations, which does not include families. ${ }^{30}$ Robert Putnam and colleagues, in their work on Italy, describe the family sphere in opposition to the "civic community," writing, "Force and family provide a primitive substitute for the civic community." ${ }^{31}$ In modernity theory, the traditional family most often shows up as a premodern form of social solidarity. A core premise of Giddens's work on intimate relationships and modernity is that traditional family ties are displaced by looser constellations based on individual interests. ${ }^{32}$ That all implies that a backsliding away from modernity, toward tribalism, would presumably include more, not less, family solidarity. And in normal conservative parlance, the "breakdown of the family" represents something more like postmodernism, or the chickens of modernity (or liberalism) coming home to roost, not a backsliding toward premodern culture. This fits

\footnotetext{
${ }^{30}$ See, e.g., the World Bank definition: World Bank. 2013. “Civil Society - Defining Civil Society.” 2013. http://go.worldbank.org/4CE7W046K0.

${ }^{31}$ Putnam, Robert D., Robert Leonardi, and Raffaella Nanetti. 1994. Making Democracy Work: Civic Traditions in Modern Italy. Princeton University Press. P. 178.

${ }^{32}$ Giddens, Anthony. 1993. The Transformation of Intimacy: Sexuality, Love, and Eroticism in Modern Societies. Stanford University Press.
} 
the concept of the "second demographic transition" as well, which is defined by later marriage and childbearing, reduced fertility, single parenthood, and non-marital relationships - demographic progress. ${ }^{33}$

In a nutshell, Goldberg clearly is part of Team Conservative, but his theory doesn't work for families. This leaves him tunneling around a problem he doesn't seem to know exists. He does some incoherent hemming and hawing about whether the nuclear family is "natural" - having just got done explaining that democratic capitalism is not natural, and that's what makes it great - while he believes the nuclear family is both "traditional" and essential to modernity. And this historical word jumble is supposed to be the resolution:

In other words, when we say that traditional marriage is 'natural,' what we really mean - or should mean - is that it is 'normal.' We made traditional marriage normal through centuries of civilizational trial and error because countless generations of wise people figured out that it was a best practice for society. And over those centuries we heaped layer upon layer of law, tradition, and custom on top of the institution. (266)

He is stuck between the political imperative to argue that contemporary family patterns - modern families - are bad, and his core argument that leftists are pushing society backwards. This leads to hapless waffling:

Our problems today can be traced to the fact that we no longer have gratitude for the Miracle and for the institutions and customs it make possible. Where there is no gratitude - and the effort that gratitude demands - all manner of resentments and hostilities flood back in. Few actually hate the traditional nuclear family or the role it plays. But many are indifferent to it. And indifference alone is enough to invite the rust of human nature back in. (277)

Needless to say, the family division of right-wing America does not normally consider gay marriage, cohabitation, and non-marital childbearing to represent the "rust of human nature." Are we to believe that capitalism and liberal democracy "make possible" the "traditional nuclear family”? What dark past in human society was dominated by such unbridled arrangements? Families have a history, it is certainly not “centuries of civilizational trial and error" by "wise people." 34 In actual history, capitalism and liberal democracy, principally including the expansion of women's rights and opportunities, have made possible advances beyond the strictures of the "traditional nuclear family." That's the positive view. For the negative view, Goldberg has only to return to the Communist Manifesto he was presumably forced to read in every American history class through which he suffered:

The bourgeoisie has torn away from the family its sentimental veil, and has reduced the family relation to a mere money relation. ... Constant revolutionising of production, uninterrupted disturbance of all social conditions, everlasting uncertainty and agitation distinguish the bourgeois epoch from all earlier ones. All fixed, fast-frozen relations, with their train of ancient and venerable prejudices and opinions, are swept away, all new-formed ones become antiquated before they can ossify. All that is solid melts into air, all that is holy is profaned, and man is at last compelled to face with sober senses his real conditions of life, and his relations with his kind..$^{35}$

\footnotetext{
${ }^{33}$ Lesthaeghe, Ron. 2014. "The Second Demographic Transition: A Concise Overview of Its Development.” Proceedings of the National Academy of Sciences 111 (51): 18112-15. https://doi.org/10.1073/pnas.1420441111.

${ }^{34}$ For a history of marriage, see: Coontz, Stephanie. 2006. Marriage, a History: How Love Conquered Marriage. Penguin Books.

${ }^{35}$ Marx, Karl, 1818-1883. The Communist Manifesto. Ch. 1.
} 
It is not the decay of progress that destroys the "traditional family," but progress itself. ${ }^{36}$

After satisfying himself that the boilerplate conservative critique of family change somehow can fit within his narrative of left-driven destruction of civilization, Goldberg turns to the standard conservative story. The quality of this chapter is summed up by the phrase, "I am deeply indebted to [W. Bradford] Wilcox's scholarship” (419), “one of America’s leading marriage researchers” (267). What follows is a straightforward recapitulation of the most mainstream thinktank views on family, based on reports from the Brookings Institution and the American Enterprise Institute. Some of this is work I have already debunked, such as the Wilcox study showing that states with more married people are richer. ${ }^{37}$

As in the case of American history, where he has serious doubts about whether schools "teach the Western tradition at all," Goldberg's world is also sadly bereft of discussions about family change. He writes, "It is remarkable that, in all the hand-wringing about the rise in economic inequality, the issue of marriage's dissolution almost never makes an appearance in the debate" (274). It is almost as if Howard Zinn runs "the debate" in this area as well. Especially lacking, Goldberg believes, is serious consideration of the role of decaying culture in driving family decline. That topic is left to such marginal political players as Marco Rubio, who listed as the first topic under "issues" on his campaign website, "Promoting Strong Families,” and specifically, "Promote a Marriage Culture.”38 Similarly, Ted Cruz’s presidential campaign issues included, "Restoring a Culture of Life, Marriage, and Family."

Conservative culture warriors share a farcical, communal sense of victimology, in which the true benefits of marriage are either rarely acknowledged or actively denied. ${ }^{40}$ In a superficial discussion of this problem, Goldberg cites a blog post by Bryan Caplan, which attempted to illustrate, in 2011, that the college earnings premium was smaller than the marriage premium for men, to make the case that economists are biased against marriage as a causal factor for success. ${ }^{41}$ I use this as an example of Goldberg's motivated weak-reasoning by digging into the data a little.

Goldberg described Caplan's result as showing, "Married men, controlling for all factors, make 44 percent more than single men” (271). Anyone familiar with the research in this area would immediately see that 44 percent as an extremely high estimate of the marriage premium for men - and also wonder why an old blog post would be the sole source for this topic, instead of the robust research literature published over several decades. ${ }^{42}$ (Also, anyone familiar with any research would know that "controlling for all factors" is never an accurate description of social science.) Caplan used the National Longitudinal Survey of Youth (NLSY), and modeled wages as a function of education, race (Black/not-Black), sex,

\footnotetext{
${ }^{36}$ However, the modern era did create the conditions for the fleeting elevation of a rarified, pseudo-traditional family, and then labeled it as the way things used to be. See, Coontz, Stephanie. 2016. The Way We Never Were: American Families and the Nostalgia Trap. Revised edition. New York: Basic Books.

${ }^{37}$ Cohen, Philip N. 2015. “Groups of People with More Income Are Richer, Wilcox Credulity Edition.” Family Inequality. October 23. https://familyinequality.wordpress.com/2015/10/23/groups-of-people-with-moreincome-are-richer-wilcox-credulity-edition/.

${ }^{38}$ Rubio, Marco. 2016. “On The Issues.” February 4, 2016. https://web.archive.org/web/20160204075151/https://marcorubio.com/issues/.

${ }^{39}$ Crus, Ted. 2016. “Life, Marriage, and Family.” February 4, 2016.

https://web.archive.org/web/20160204075842/https://www.tedcruz.org/issues/life-marriage-and-family/

${ }^{40}$ I devote a chapter to this issues in Cohen (2018), op cit.

${ }^{41}$ Caplan, Bryan. 2012. “The College Premium vs. the Marriage Premium: A Case of Double Standards.” Econlib. 2012. http://www.econlib.org/archives/2012/01/the_college_pre.html.

${ }^{42}$ My own research on men's marriage premium, fortunately now completely obsolete, was published in 2002. See, Cohen, Philip N. 2002. "Cohabitation and the Declining Marriage Premium for Men.” Work and Occupations 29 (3): 346-63.
} 
work experience (not defined), marital status, number of children, and an IQ proxy. Goldberg writes, "the wage benefit of marriage is roughly equal to, if not greater than, that of going to college." However, the model in the blog post did not answer that question, as it compared the effect of marriage for men to the effect of a BA for both men and women combined. And for no good reason, his model compared wages of BAs to wages of high school dropouts, which is not useful.

Caplan's model showed a benefit of .44 (in log wages, which is not the same as 44 percent) for male marriage versus .34 for a BA. I am not expert in NLSY analysis, but a quick scan of earnings papers using that dataset shows two published examples where marriage brings a much smaller benefit, equivalent to one only or two years of education. ${ }^{43}$ More importantly, recent research that carefully considers the sequence of events in men's lives - using longitudinal analysis - rather than simply comparing earnings between those who are married and those who aren't, finds no evidence of a causal effect of marriage on men's earnings - and that is what matters when one is promoting the idea of marriage as a way to increase earnings. ${ }^{44}$ Men who already earn more, or are already on an upward earnings trajectory, are more likely to get and stay married, which is why married men make more money - so suggesting that marriage will increase earnings is not supported by the evidence.

Although longitudinal analysis is necessary to answer the causal question it still is an important observation that married men earn more than single men - that's a social fact, which Goldberg suggests reveals a bias against studying marriage. However, that advantage is substantially smaller than the advantage associated with a college degree. I illustrate this using the most recent American Community Survey in Figure 3, for both men and women. This comparison holds constant a set of standard demographic variables (which is not "controlling for all factors"), and shows the average marginal effect of marriage versus education ("effect" here in a statistical sense, not the causal sense), or what the earnings would be for a hypothetical average person who switched values on just these variables. It shows that this average married man would earn about $\$ 10,700$ more married than he would if he were single (compared with about $\$ 2,900$ for a woman), versus a boost of about \$38,700 from moving to a BA from a high school diploma (compared with $\$ 29,000$ for women). Again, this is not a causal model, but it shows the relative size of the earnings advantage associated with marriage and education that is not accounted for by important demographic variables. Based on this and the other research cited, the Caplan result is anomalous, and Goldberg's superficial reading of it is wrong.

${ }^{43}$ Blackburn, McKinley L. 2007. "Estimating Wage Differentials without Logarithms.” Labour Economics 14 (1): 73-98. https://doi.org/10.1016/j.labeco.2005.04.005. Regan, Tracy L. and Ronald L. Oaxaca. "Work experience as a source of specification error in earnings models: implications for gender wage decompositions, IZA

Discussion Papers, No. 1920, Institute for the Study of Labor (IZA), Bonn. https://www.econstor.eu/bitstream/10419/33318/1/506211657.pdf.

${ }^{44}$ Killewald, Alexandra, and Ian Lundberg. 2017. "New Evidence against a Causal Marriage Wage Premium.” Demography 54 (3): 1007-28. Ludwig, Volker, and Josef Brüderl. 2018. "Is There a Male Marital Wage Premium? New Evidence from the United States.” American Sociological Review, Online July 9. 


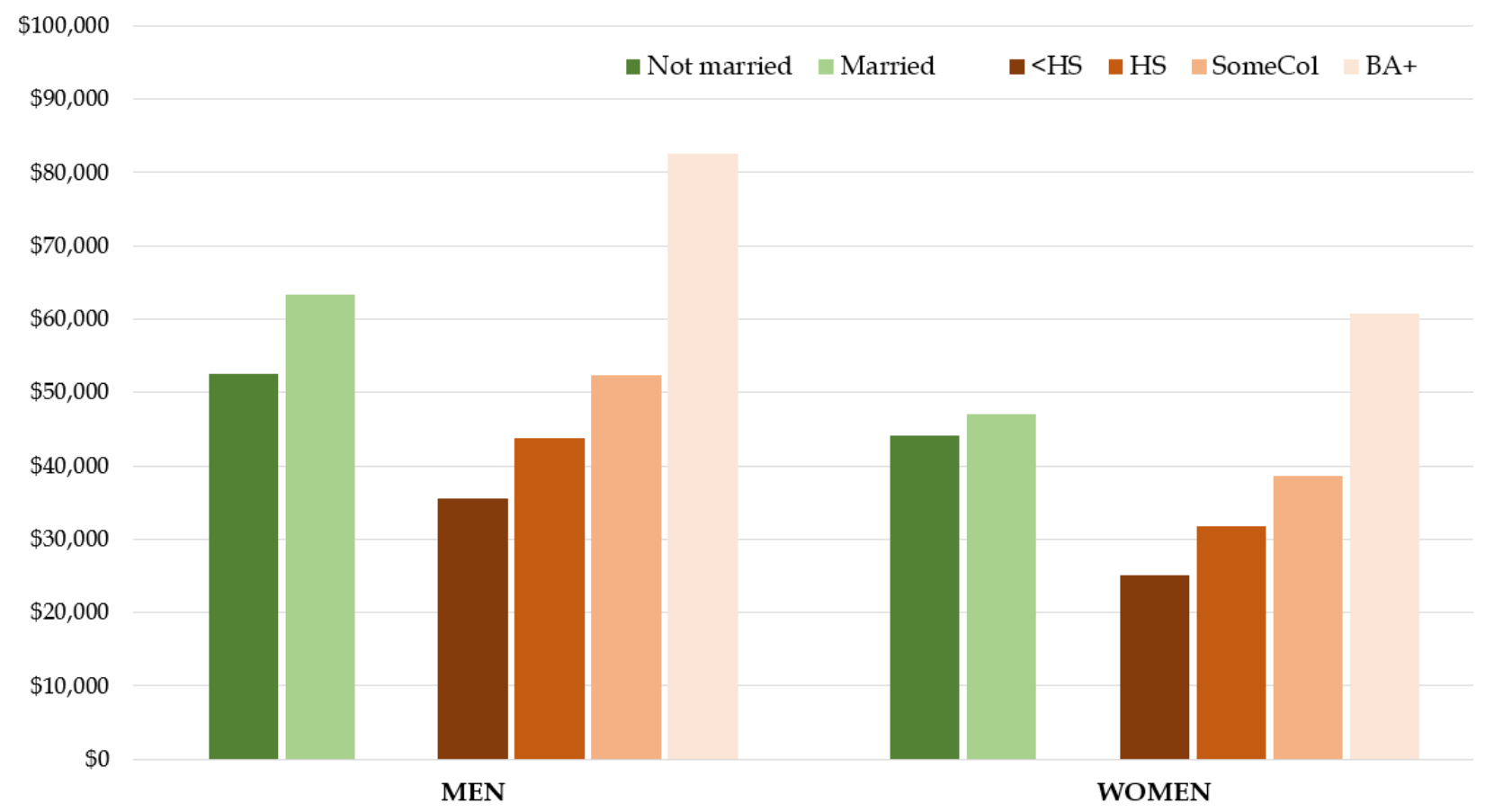

Note: Separate models for men and women, ages 25-64. Dependent variable was logged earnings, exponentiated here or illustration. Control variables: Age, age-squared, race, Hispanic origin, nativity, number of children, presence of own child under age 5, disability. Unweighted. Data source: American Community Survey via IPUMS.org. PN Cohen chart.

Figure 3. Average marginal effects of marriage and education on annual earnings for full-time, year-round workers: U.S., 2016

Goldberg's discussion of the "success sequence" also stands out. This is the idea that people who finish high school, get and keep a full-time job, and marry after age 21, before having children, will have low poverty rates, supposedly as a result of following these "steps" in sequence. I and many others have criticized this concept, which is proposed as a marketing slogan for upward social mobility. ${ }^{45}$ After falsely attributing the idea to Brookings researcher Ron Haskins, Goldberg writes of the sequence, "If young people do just these three things, in that order, they are almost guaranteed to climb out of poverty" (271). First, no one has tested whether the success sequence works for "climbing out" of poverty; it is only used to show that people who have followed it are not subsequently in poverty. Second, as has been repeated ad nauseam by critics of this meme, poverty rates are extremely low for anyone with a high school degree and a full-time job, especially as the official poverty line is determined by pre-tax cash income, which comes almost exclusively from labor market earnings. The official poverty rate for people with a high school degree and a full-time, year-round job in 2017 was 3.5 percent for men and 5.6 percent for women (my calculations from the Current Population Survey). So without considering any family characteristics or the sequence of life course events, one could say people who met "just" these two criteria are "almost guaranteed" not to be in poverty. In other words, the "simple rules" Goldberg and others advocate for getting out of poverty amount to, “don't be in poverty."

\footnotetext{
${ }^{45}$ Cohen, Philip N. 2018. “The Failure of the Success Sequence.” Cato Unbound. May 16. https://www.catounbound.org/2018/05/16/philip-n-cohen/failure-success-sequence.
} 


\section{In conclusion, racism}

One of Goldberg's false claims turns out to be pivotal. "It is a cliché of the left," he writes, "to say that, 'perception is reality"” (233). I noted in the first version of this essay that this phrase is not "of the left," but was introduced to American politics by Republican propaganda strategist Lee Atwater in the 1988 presidential campaign. ${ }^{46}$ Shortly after that, Michiko Kakutani released The Death of Truth, which makes clear the origin and implications of this idea for today:

When the Republican strategist Lee Atwater observed in the 1980s that "perception is reality," he was bluntly articulating an insight about human psychology that Homer well knew when he immortalized Odysseus as a wily trickster, adept at deception and disguise. But Atwater's coldblooded use of that precept in using wedge issues to advance the GOP's southern strategy - and to create the infamous Willie Horton ad in the 1988 presidential campaign - injected mainstream American politics with an alarming strain of win-at-all-costs Machiavellianism using mass media as a delivery system. ${ }^{47}$

The importance of that racist context is made clear in the passage that follows from Goldberg, where he argues that Whites are becoming more "tribal" because of leftist "bigotry" against them. He goes on:

Well, the perceived reality for millions of white, Christian Americans is that their institutional shelters, personal and national, are being razed one by one. They do not like the alternatives they are being offered. Some fraction may indeed be racists, homophobes, or Islamaphobes, but most simply don't like what they are being offered because they do not know it or because they do know it but prefer what they perceive to be theirs. And yet people like Sanders insist that resistance to their program is not just wrong but evil. The grave danger, already materializing, is that whites and Christians respond to this bigotry and create their own tribal identity politics. (233).

So Goldberg falsely attributes the "perception is reality" approach to the left, then blames the left for making whites into racists. A correct reading off the history back to Atwater and the southern strategy points instead to decades of racist propaganda from Goldberg's Republican Party, which generated and then happily used such "perceived reality" to whip up support for its agenda. Goldberg and other conservatives now may be disappointed that the white tribalist tail now appears to be wagging the onepercent dog, but blaming the left is disingenuous.

With that backdrop, Goldberg arrives to the chapter on "The Trumpian Era," subtitled, "The Perils of Populism.” The glaring hole in that chapter is found in the center, where any serious discussion of Whiteness and racism would be. Goldberg writes that Trump, "represents a reversion to a natural type of leader who speaks and thinks in tribal terms" (290), but does not mention in this chapter that the tribe in question is White Americans. This reaches the point of bizarreness when Goldberg complains that Trump doesn't represent all Americans, but rather "the people his supporters believe to be the only people who matter" (293), and "his definition of who qualifies as the American people often begins and ends with those Americans who support Donald Trump” (293-294) - with still no mention of their racial

\footnotetext{
${ }^{46}$ Salamon-Abrams, Roxie. 2017. "Echoes of History? A Lesson Plan About the Recent Rise of Europe’s Far-Right Parties.” New York Times, December 22. https://www.nytimes.com/2017/04/19/learning/lesson-plans/echoesof-history-a-lesson-plan-about-the-recent-rise-of-europes-far-right-parties.html.

${ }^{47}$ See: Kakutani, Michiko. 2018. The Death of Truth: Notes on Falsehood in the Age of Trump. New York: Tim Duggan Books. p. 79.
} 
(ethnoracial, ethnonational) identity. Goldberg almost mentions Trump’s “populist and nativist appeals,” but never mentions the Whiteness of the appealees or the non-Whiteness of their targets.

This absence of race leads to some nonsensical description. One simply cannot coherently describe Trump's base as economically insecure without acknowledging the racial intersection, because of course minorities on the whole are more insecure than Whites, and they are not a part of Trump's base. (You might think that was blindingly obvious by the end of 2017, but that would be to underestimate the impenetrability of the bubble which Goldberg apparently inhabits.) So in the Trump chapter, when Goldberg moves to inequality, you get word salad like this: "But while it is important to note that income inequality has heightened in large part because the rich got richer and the middle class got much bigger" and here I interject to say that's not how math works - "that doesn't change the fact that a big chunk of Americans are stuck. And they just happen to be a disproportionate share of Donald Trump's base” (308). If, as Goldberg surely knows, Trump's base is White, why isn't the stuck Black community lining up behind him? To answer that question is to address the true character of the movement; ignoring it leads to the kind of vacuous analysis that only I Don't See Race-ism can produce.

All of which is not to say that race and ethnicity are not part of Goldberg's story. Blacks and racism against them specifically is strikingly absent, but immigration figures prominently - proposed as a mechanism undermining civil society and driving Whites off their civilized perch and down toward tribalism. The following passage includes a stunning chain of causal logic unburdened by evidence, through which immigration emerges as a core problem in U.S. society:

Mass immigration erodes mediating institutions, and the decline of these authentic communities fuels the migration to 'virtual communities' online where resentments are reinforced as like congregates with like, lending support to statements and attitudes we would normally never express in real life. This reinforcement encourages people to say them in real life. The resulting backlash is then celebrated as 'winning' on the Internet, which can be increasingly monetized. Immigration and economic churn make people feel insecure, so they go on Facebook, where people curate their lives to make it seem like everything is going swimmingly, and this breeds feelings of envy and status/class anxiety. (325)

Immigration literally drives "people” (always raceless, like Goldberg himself) online, where they become less civil, and more anxious. The resulting insecurity and backlash make "people” vulnerable to Trump's "populism," which starts with P and that rhymes with $\mathrm{T}$ and that stands for Tribalism. The head spins. ${ }^{48}$

Although he never sews this up, when he finally touches on White identity, it is to place its emergence in the historical stream propelled by leftist identity politics and fueled by immigration. "Conservatism was moving in the direction of identity politics for white people long before Trump," he concludes, "and it may have ended up where it is today sooner or later had he never run for president” (326). That's an interesting comment, but he never explains this long-term development. Instead he turns to the "precipitating cause for the right's surrender to populism and tribalism ... the failure of the Tea Parties" (parties he himself labored to support) which was ultimately caused by the way they were "demonized by the media and Hollywood as racist yokels and boobs” (326). That elite characterization, applied to Goldberg as well, apparently still rankles.

\footnotetext{
${ }^{48}$ Back on the question of families and civil society, note here that if "mass immigration erodes mediating institutions," Goldberg has again dropped families from the category of mediating institutions, or at least immigrant families, as immigrant families are more likely to be of the "traditional nuclear" form than are those formed by the native born.
} 
Anti-Trump conservative intellectuals could still play a positive role as the crisis of Trumpism unfolds. However, by blaming leftism and immigration for the crisis, and tying it to the general decay of society, Goldberg instead sets up conservatism to find common ground with Trumpism against a historic enemy. This is not a good book, but the outlook it portends is worse. 


\section{Appendix A: Who doesn't answer the race question?}

When people answering Census Bureau surveys don't provide their race, either by refusing in person or leaving the question blank on their forms, the bureau uses an allocation procedure to make an educated guess about their race, based on other available information, such as the race of household members. And then they tag the people whose race values were allocated, so researchers are forewarned the data may be suspect. ${ }^{49}$ Among the adults with assigned races on the American Community Survey (ACS), the largest survey, the bureau's algorithm classified 83 percent as White (for these calculations I excluded Hispanics, many of whom don't answer the race question because they just answered a question about Hispanicorigin and they don't know how to pick from a list of races that doesn't include their identity ${ }^{50}$ ). Onepoint-two percent of Whites have an allocated race response, the highest proportion of any group except "other race," which is very small (once Hispanics are removed). This is about twice the rate of allocation for Blacks.

In Figure A1 the blue bars show the number of adults not reporting a race (these are weighted, so they are an estimate of how many people who would have refused to answer if the survey had been administered to the whole population). The brown bars show the percentage of each group that had their race allocated by the bureau. These are based on marginal effects from a logistic model that controls for age, sex, education, nativity, region, and survey response mode (in person, internet, phone). This shows that a relatively large share of Other race respondents got that identification from the bureau rather than offering themselvtes. After that, the multivariate model confirms that the group with the highest likelihood of having allocated race response is Whites.

Fig A1. American Community Survey allocated race: Adults, 2016

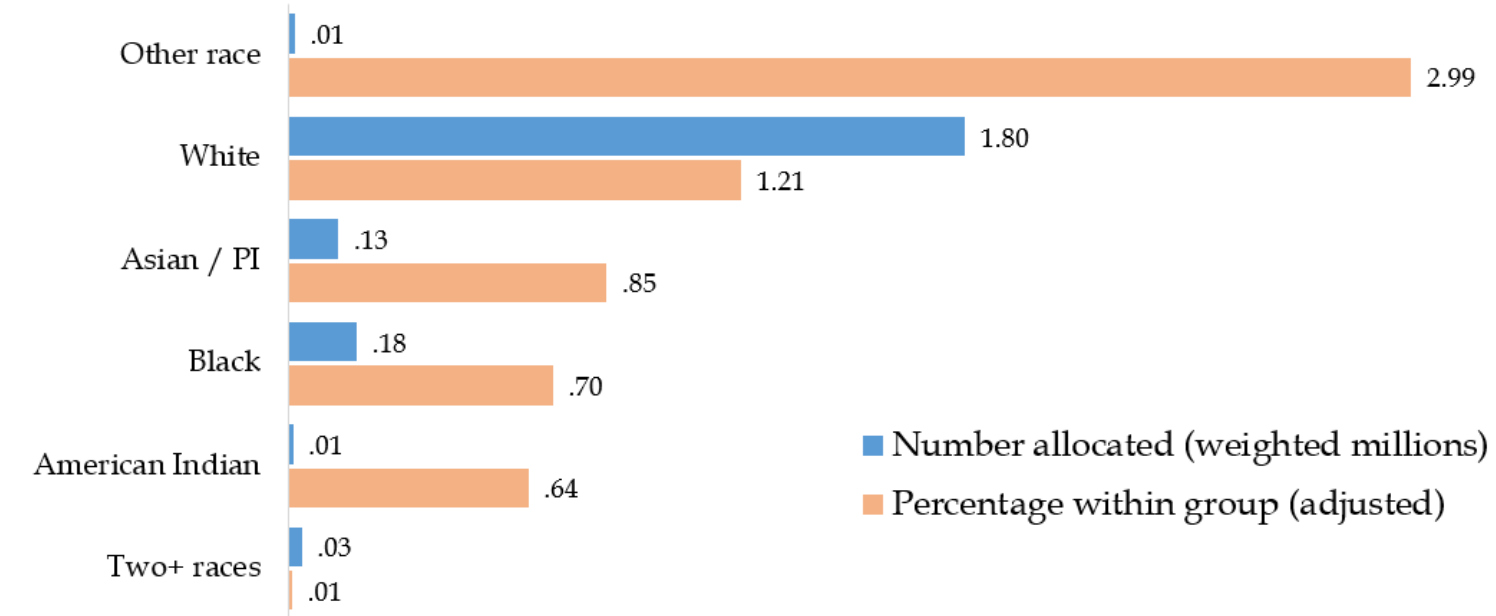

Note: Hispanics excluded. Data source: American Community Survey via IPUMS.org. Adjusted percentages are marginal effects from a logistic model that controls for age, sex, education, nativity, region, and survey response mode.

${ }^{49}$ US Census Bureau. 2018. “Design and Methodology Report.” 2018. https://www.census.gov/programssurveys/acs/methodology/design-and-methodology.html.

${ }^{50}$ Cohn, D’Vera. 2017. “Seeking Better Data on Hispanics, Census Bureau May Change How It Asks about Race.” Pew Research Center. April 20. http://www.pewresearch.org/fact-tank/2017/04/20/seeking-better-data-onhispanics-census-bureau-may-change-how-it-asks-about-race/. 
There is another way to look at how race-refusers see themselves, and that is the ancestry question. On the ACS, respondents are offered the opportunity to write in any ancestry they like, and the bureau then codes the responses (leaving out religious identities, out of misplaced adherence to the First Amendment). For Figure 2, I took the twenty largest ancestries reported, and looked at the percentage of each group that didn't answer the race question (again excluding Hispanics). Figure A2 shows, for example, that 1.2 percent of people who gave "United States" as an ancestry (out of an estimated 17 million) left race blank, and the vast majority of them were allocated by the bureau to the White race category. On the other hand, among the estimated 29 million who offered African-American or Afro-American, only 0.2 percent didn't offer a response to the race question, and the majority of them were coded into the Black race category. Overall, this is also consistent with the conclusion that race refuseniks are overwhelmingly White.

Fig A2. Percentage of the 20 largest ancestry groups that did not answer the race question, with the Census Bureau's allocated race (non-Hispanics only)

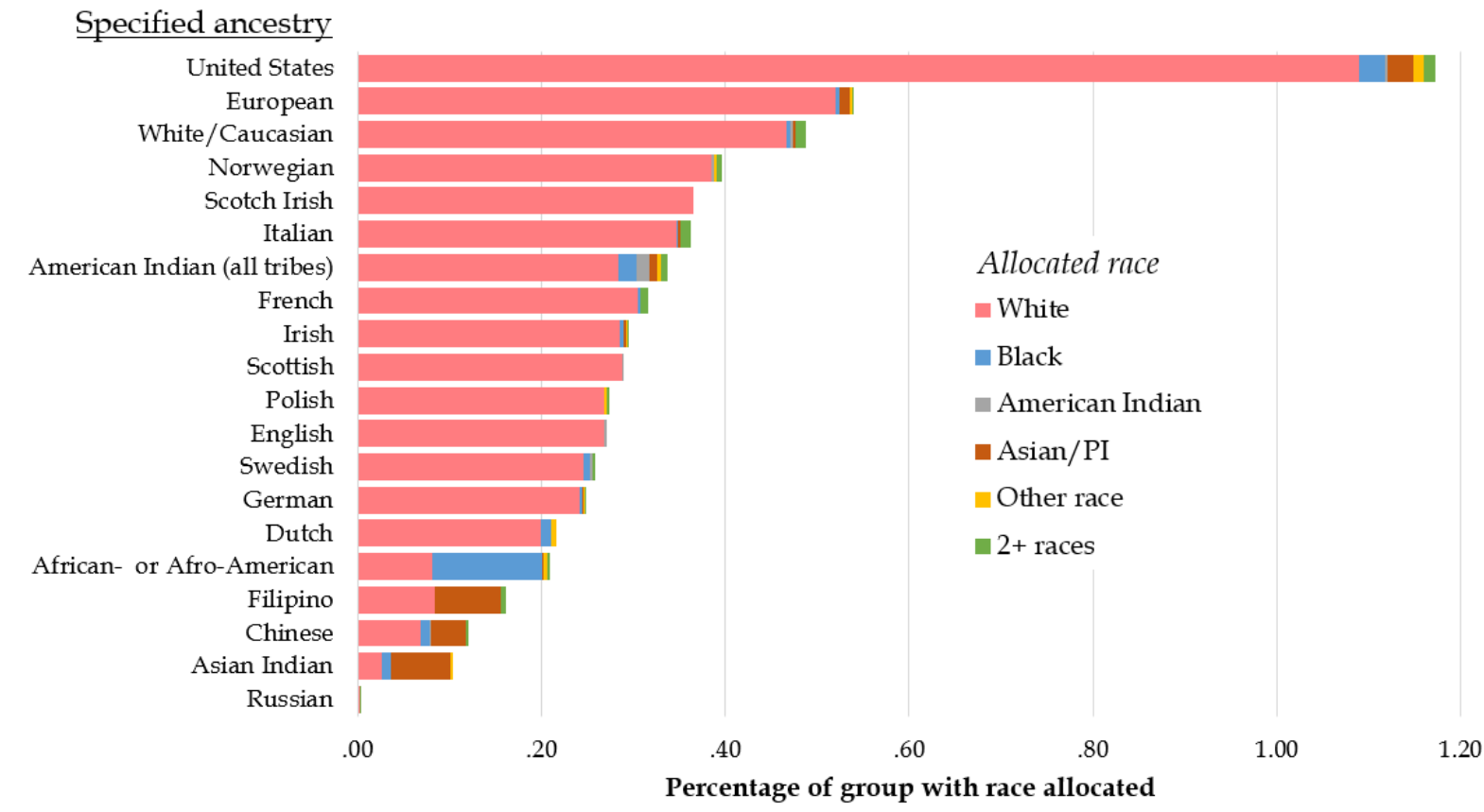

Note: Ancestry is an open-ended question. For example, 1.7 million people (weighted) specified "United States" as their ancestry, and 202,000 of them did not specify a race (1.17\%). The Census Bureau coded $93 \%$ of those as White, based on other information, such as household members' race. Hispanics are excluded because many don't report race. Data source: 2016 American Community Survey data via IPUMS.org. 


\section{Appendix B. The earnings advantage of married men}

I used ordinary least squares models with logged annual earnings as the dependent variable, on marriage, education, and common control variables, for full-time, year-round workers (50+ weeks, 35 hours or more usually worked per week) age 25-64. Table B1 shows the descriptive statistics from the 2016 American Community Survey. Table B2 shows the regression results. The models here are combined, and for men and women separately. The estimates from the separate models are used to generate Figure 3 in the text, showing the average marginal effects of marriage versus education, confirming that the adjusted difference between higher and lower education workers is much greater than that between married and non-married workers.

The data and code used to generate these results, and a spreadsheet with the results and the figure, are available in an Open Science Framework project at: https://osf.io/mnj4c/.

Table B1. Means of variables used in the analysis

\begin{tabular}{|c|c|c|c|c|c|}
\hline & Total & Men & Women & Min & Max \\
\hline Annual earnings (natural log) & 10.819 & 10.929 & 10.679 & 1.39 & 13.48 \\
\hline Married & .637 & .678 & .585 & 0 & 1 \\
\hline \multicolumn{6}{|l|}{ Education } \\
\hline$<\mathrm{HS}$ & .065 & .080 & .046 & 0 & 1 \\
\hline HS & 289 & .312 & .261 & 0 & 1 \\
\hline SomeCol & .240 & .228 & .255 & 0 & 1 \\
\hline $\mathrm{BA}+$ & .406 & .380 & .438 & 0 & 1 \\
\hline \multicolumn{6}{|l|}{ Female } \\
\hline Age & 44.5 & 44.4 & 44.6 & 25 & 64 \\
\hline \multicolumn{6}{|l|}{ Race } \\
\hline White & .783 & .798 & .705 & & \\
\hline Black & .091 & .075 & .112 & 0 & 1 \\
\hline AIAN & .008 & .008 & .009 & 0 & 1 \\
\hline Asian/PI & .060 & .059 & .062 & 0 & 1 \\
\hline Other race & .037 & .041 & .062 & 0 & 1 \\
\hline Two major races & .018 & .017 & .032 & 0 & 1 \\
\hline Three or more major races & .002 & .002 & .018 & 0 & 1 \\
\hline Latino & .132 & .139 & .123 & 0 & 1 \\
\hline Foreign born & .164 & .174 & .151 & 0 & 1 \\
\hline Number of own children & .910 & .951 & .858 & 0 & 9 \\
\hline Any child < 5 & .129 & .145 & .107 & 0 & 1 \\
\hline Disability & .049 & .049 & .048 & 0 & 1 \\
\hline $\mathrm{N}$ & 872,261 & 489,428 & 382,833 & & \\
\hline
\end{tabular}

Data source: 2016 American Community Survey; Full-time, year-round workers ages 25-64. 
Table B2. OLS coefficients for logged earnings on marriage, education, and other variables

\begin{tabular}{|c|c|c|c|}
\hline & Total & Men & Women \\
\hline Married & $.127 *$ & $.186^{*}$ & $.062 *$ \\
\hline \multicolumn{4}{|l|}{ Education } \\
\hline$<\mathrm{HS}$ & -- & -- & -- \\
\hline HS & $.220 *$ & $.211 *$ & $.237 *$ \\
\hline SomeCol & $.406 *$ & $.390 *$ & $.430 *$ \\
\hline $\mathrm{BA}+$ & $.864 *$ & $.845 *$ & $.884 *$ \\
\hline Female & $-.283 *$ & -- & -- \\
\hline Age & $.062 *$ & $.063 *$ & $.063 *$ \\
\hline $\operatorname{Age}^{\wedge} 2$ & $-.001 *$ & $-.001 *$ & $-.001 *$ \\
\hline \multicolumn{4}{|l|}{ Race } \\
\hline White & -- & -- & -- \\
\hline Black & $-.174 *$ & $-.247 *$ & $-.110 *$ \\
\hline AIAN & $-.158 *$ & $-.178 *$ & $-.128 *$ \\
\hline Asian/PI & $.033^{*}$ & -.009 & $.087^{*}$ \\
\hline Other race & $-.051 *$ & $-.062 *$ & $-.030 *$ \\
\hline Two major races & -.010 & $-.036 *$ & .023 \\
\hline Three or more major races & .014 & -.016 & .043 \\
\hline Latino & $-.112 *$ & $-.139 *$ & $-.077 *$ \\
\hline Foreign born & $-.056 *$ & $-.058 *$ & $-.049 *$ \\
\hline Number of own children & $.015 *$ & $.029 *$ & $-.017 *$ \\
\hline Any child $<5$ & $.048 *$ & $.016^{*}$ & $.087 *$ \\
\hline Disability & $-.128 *$ & $-.138 *$ & $-.118 *$ \\
\hline Constant & $8.821 *$ & $8.776 *$ & $8.561 *$ \\
\hline $\mathrm{N}$ & 872,261 & 489,428 & 382,833 \\
\hline $\mathrm{r} 2$ & .284 & .278 & .252 \\
\hline
\end{tabular}

$* p<0.001$

Data source: 2016 American Community Survey; Full-time, year-round workers ages 25-64. 